\title{
The Calculation of the Remaining Results of Operations of Statements Financial and Cooperative Performance on KSP Usaha Jakarta Branch Office
}

Achmad Fauzi* and Sofyan Marwansyah

Faculty of Economics, University of BSI, Jakarta Timur, Indonesia

\begin{abstract}
KSP Usaha Mandiri is a cooperative engaged in lending service. The purpose of this research is to know the results of the remaining results in the division of and the performance of KSP Usaha Mandiri, Jakarta Branch Office. Of the remaining result is an income earned on cooperative. The results are derived based on revenue total minus costs total and liabilities within one year of the book concerned. Data collection methods in the preparation of the final project is a method of observation, interviews, and methods library study where the method of discussion used is qualitative descriptive, the method of data without using statistical method. In the division of the remaining results there are principles of division of the remaining results of sourced from members, the remaining results are services from capital and transactions own members, the division of the remaining results operations carried out transparently, the remaining results of the proceeds paid in cash. The role of the remaining results in the statements financial is very important to know the calculation in the division of the remaining results to members. In the period 2014-2016 there has been an increase of the remaining results obtained by KSP Usaha Mandiri. There are several factors that can influence the increase of the remaining results in the cooperative in the capital which consist of principal savings and mandatory savings and participation of members.
\end{abstract}

Keywords: Principles of division of time results of operations; Role of operating results

\section{Introduction}

Analysis and literature review framework:

\section{Cooperative}

Understanding cooperatives: According to Law No. 17 of 2012 provides the limitation that "Cooperatives are legal entities established by individuals or cooperative legal entities, with the separation of their members' assets as capital to run businesses, which fulfil their shared aspirations and needs in the economic, social and cultural fields in accordance with the values and cooperative principles". Cooperatives become the legal basis for the economic development of democracy and economy based on PANCASILA and the 1945 Constitution, affirming that the position of cooperatives as a legal entity, affirmation of the principle and purpose of cooperatives, inauguration of the principle as the identity of the Indonesian cooperative, in service to members, creativity and capital development of cooperatives. Hendrojogi [1] provides the limitation that "Cooperative is a business entity consisting of people or legal entity cooperatives with the principle of cooperatives as well as a people's economic movement based on the principle of kinship". In general, the cooperative is a business entity formed in which members of cooperative people or legal entities based on the principle of cooperatives based on the principle of kinship. Sudarwanto [2] provides the limitation that "Cooperative is an association established by people or legal entity of cooperatives that have limited economic ability, with the aim to fight for improving the welfare of its members". In general, the cooperative has a purpose to improve the welfare of members, and then each member is obliged and has responsibility to develop and oversee the cooperative effort. To realize the objectives of the cooperative, the established business entities that have business activities that are managed democratically as a consequence of the role or participation members in developing cooperative business, the risks and benefits of co-operative business together and shared fairly. From some theories can be concluded that the cooperative is a legal entity that has a purpose to improve the economic welfare of members in particular. Because in general, working on the association of cooperatives are people from the weak economic class fate and aims. In addition, the cooperative is based on the principle of cooperative based on the principle of kinship. Then the main characteristics of the cooperative that distinguishes it from other business entities, i.e. members of the cooperative have multiple identities. The dual identity means cooperative members are the owners and users of cooperative services. Generally cooperatives are jointly controlled by all members, where each member has the same voting rights in every decision taken by the cooperative.

Understanding cooperative savings and loans: Savings and loans cooperatives are established to allow members to easily and easily borrow money. The savings and credit cooperatives seek to prevent their members from engaging in bondage by loan sharks when they need some money by activating savings and arranging lending money with the lowest interest.

Burhanuddin [3] gives the limit that "Cooperative savings and loans is a cooperative established to provide an opportunity for its members to obtain loans on the basis of goodness".

In general, savings and loan cooperatives is an established cooperative where in order to provide opportunities in obtaining loans to its members because on the basis of goodness owned by its members.

Rudianto [4] provides the limitation that "Cooperative savings and loans is a cooperative engaged in the fertilization of funds deposits of its members, to then be loaned back to the members who need financial assistance.

*Corresponding author: Achmad Fauzi, Faculty of Economics, University BSI Bandung Education, Jakarta Timur, Indonesia, E-mail: achmad_fauzioke@yahoo.com

Received May 23, 2018; Accepted June 26, 2018; Published July 10, 2018

Citation: Fauzi A, Marwansyah S (2018) The Calculation of the Remaining Results of Operations of Statements Financial and Cooperative Performance on KSP Usaha Jakarta Branch Office. J Account Mark 7: 284. doi: 10.4172/2168-9601.1000284

Copyright: @ 2018 Fauzi A, et al. This is an open-access article distributed under the terms of the Creative Commons Attribution License, which permits unrestricted use, distribution, and reproduction in any medium, provided the original author and source are credited. 
In general, savings and loan cooperatives in the field of acceptance of funds or funds can be said of the capital of its members to then be loaned back to the members who need funds. The main activity of saving and loan cooperatives is to provide storage and lending services to members of cooperatives whose interest rates are not too high and in accordance with the rules of cooperatives.

Widiyanti and Sunindhia [5] concluded that: Savings and loans cooperative is a cooperative engaged in the business field of capital formation through members' savings regularly and continuously to then lent to the members in a way easy, cheap, fast and precise for productive and welfare purposes.

The savings and loans cooperative raise funds from its members which then redistributes to its members. Savings and loan cooperatives have a goal to educate its members to save lives and increase their members' knowledge of cooperatives. To achieve its objectives, savings and credit cooperatives must implement rules on the roles of management, oversight, and most importantly the meeting of members.

From several theories can be concluded that the savings and loan cooperative is a financial institution engaged in the savings and loan money that is owned with capital derived from member's savings and lent to members who require. And managed by its members, and aims to prosper its members, educate members in living frugality and increase knowledge to members about cooperatives.

Cooperative function: The characteristics of the Indonesian cooperative have given birth to a distinctive function of the Indonesian cooperative. These cooperative functions of Indonesia are listed in Article 4 of Law No.12 of 1967, among others:

1. The instrument of economic struggle to enhance the welfare of the people.

2. National economic democracy tool.

3. Cooperative as one of the economic pulse of the nation of Indonesia.

4. Community foster tool to strengthen the economic position of the Indonesian nation and unite in regulating the people's economic governance.

The cornerstone of cooperatives: To make the cooperative as a pillar of the Indonesian economy, the Indonesian cooperative must have a strong foundation for the cooperative building not to collapse if faced with challenges in society. This foundation is a foothold that allows cooperatives to grow, stand up and grow in running their business to achieve the goals aspired. The cornerstone of the cooperative consists of three bases based on Article 2 of Law No.12 of 1967, among others:

The foundation of Indonesian cooperative idiil: What is meant by the basic foundation of a cooperative is the foundation or foundation used in an effort to achieve cooperative ideals. The cooperative as a group of people aims to achieve a just and prosperous society. So the goal is the same as what is aspired by the entire nation of Indonesia. Therefore the State of the Republic of Indonesia is PANCASILA. Therefore, pancasila with the five crosses are:

- Belief in the one and only God.

- Just and civilized humanity.

- The unity of Indonesia.
- Democracy led by the wisdom of wisdom in deliberations of representation.

- Social justice for all the people of Indonesia should be the basis or foundation and implemented in cooperative life, because the precepts are indeed the nature of the cooperative objectives and forever the aspirations of members of the cooperative. This ideative basis must be practiced by the cooperative.

The structural platform and the motion of Indonesian cooperatives: What is meant by the foundation of a cooperative structure is the foothold of the cooperative in the composition of social life. In Indonesia the 1945 constitution applies which the provision is for basic rules governing the implementation of the philosophy of life and moral ideals of a nation and because the cooperative in Indonesia is the 1945 Constitution. In the life of the people of Indonesia one important part is the life economic activities and efforts to regulate and achieve or meet the needs and necessities of life. All these activities and businesses have also been regulated in the 1945 Constitution Article 33 paragraph 1 of the 1945 Constitution which reads "the economy is organized as a joint effort based on the principle of kinship". And in the explanation of Article 33 paragraph 1 of the 1945 Constitution stated that the establishment of business in accordance with it is cooperative. Thus cooperative is the embodiment of Article 33 paragraph 1 of the 1945 Constitution 3. The Foundation of Mental Cooperative Indonesia Mental Platform Cooperative Indonesia is a loyal friend and conscious personality. This nature is reflected in the form of actions and real behavior as activities mutual assistance. But the foundation of friendship alone can only maintain communion in a static society is not dynamic and therefore not can drive progress. Therefore, the loyalty of friends must be accompanied by an awareness of personal self-esteem, the conviction of self-esteem and self-belief is essential to raise the level of livelihood and prosperity. Therefore, in the cooperative should be incorporated the two mental foundations above, namely loyal friends and personal consciousness as two elements that push-push, life-life, and watch-out.

Cooperative principles: The distinction between cooperatives and other business entities lies not only in their foundations and principles but also on the principles of organizational and business management they follow. The principles of cooperative management are further elaboration of the principle of kinship adopted. This cooperative usually arranges both the relationship between the cooperative with its members, the relationship between fellow members of the cooperative, the pattern of organizational management of the cooperative as well as on the goals to be achieved by the cooperative as an economic institution based on kinship. In addition, cooperative principles usually also regulate the pattern of business management cooperative. Therefore, in detail these principles also regulate the pattern of capital ownership of cooperatives as well as the pattern of distribution of the remaining results of its business. Preparation of cooperative principles in Indonesia cannot be separated from the history and development of international cooperative principles. As stated in Article 5 paragraph 1 of Law No. 25 of 1992, Indonesian cooperatives implement the principles among others:

- Membership is voluntary and open.

- Management is done democratically.

- The division of the net proceeds is done fairly and is proportionate to the size of the services of each member.

- The giving of remuneration is limited to capital

- Independence 
The cooperative does not use the term profit or profit to show the difference between the income received during a certain period and the sacrifices incurred to earn that income. This disagreement in the cooperative is also called the Time of Business Result (SHU). This SHU after deducted by certain fees will be distributed to the members in accordance with the consideration of their services. Member services are measured by their respective contributions to SHU formation. The contribution size used is the number of member transactions with the cooperative over a certain period.

\section{Remaining business results}

Understanding the remaining business results: Based on UU. No. 12 Year 1967 article 34 concludes that:

- The rest of the business result is the income of the cooperative obtained within one year of book after deducting the depreciation, and the expenses of the relevant fiscal year.

- It stipulates that the remaining business proceeds stem from business held for members and non-members.

- It also states that the remaining results of operations derived from the business held for members are divided for social funds. It can also mean that social funds are based on the profits earned in the fiscal year, because the so-called profit is essentially the income of the cooperative after deducting the costs.

Democracy has a strong root in the cooperative ideals of justice, freedom and mutual cooperation and as a result seeks to "humanize" corporate controls to the extent possible without the sacrifice of corporate efficiency. Therefore, the cooperative always declares itself as a collection of people and not a collection of capital, until the control of the company is in member meetings as the highest strength on the basis of equal voting rights for all members is one member one vote, regardless of magnitude capital members planted in cooperatives. Restriction of interest on capital invested in cooperatives is another feature in placing capital in a lower position.

Limbong [6] gives the restriction that "The rest of the business results is the difference of total income or total revenue with the costs or total cost in one book year". In general, the amount of residual income received by a member will vary, depending on the amount of capital participation and member transactions on the formation of cooperative income. The bigger the transactions (business and capital) members with the cooperative, the greater the residual income of business results to be received. According to Sudarwanto [2], the rest of the cooperative's business is the difference between the received income and the burden of responsibility of the cooperative during the accounting period, before being allocated to various funds. The remaining results of the business appear on the financial statements of cooperatives on a monthly basis". In the cooperative is not known by the term "profit", because the cooperative business activities the main purpose is not profit-oriented oriented but rather oriented to the benefits. Basically cooperatives are managed with the aim of prospering members and society. The remaining operating results of the current period represent the difference between earned income and expense which is the responsibility of the cooperative during the accounting period, before being allocated to various funds. The remaining results of this business appear on the financial statements on a monthly basis. However, in the annual financial statements after the concluding paragraph and allocating the remainder of the proceeds into various funds, this estimate does not appear in the annual report. From the above theories can be concluded that the rest of the business result is the income of the cooperative obtained in one book year minus the cost that can be accounted for, the depreciation that must be paid in the relevant fiscal year. The rest of the proceeds from the business held for members are shared for social funds. The remaining business results appear on the financial statements on a monthly basis and do not appear in the annual report.

The distribution of the cooperative business's remuneration: On the way and the magnitude of the distribution of the rest of the business proceeds by UU. No. 12 Year 1967 is submitted to the agreement of the members of the cooperative which is then poured into the cooperative ART. There shall also be a separation between the use of income derived from the services of the members themselves and against any third party including non-members. SHU shares obtained from services to third parties, including non-members are not distributed to members, since this portion of income is not derived from services member. Therefore, SHUs from members in cooperative activities are distributed to cooperative reserves, for members comparable with the services they provide, to board funds, personnel funds, cooperative education funds, social funds, and regional development budgets. SHU from non-member businesses is distributed for all the abovementioned aspects except for its members, i.e. for cooperative reserves, board funds, employee funds, education funds, social funds, regional development funds.

SHU distribution principles: The member of the cooperative has two dual functions, namely the owner (Owner) and as the customer (Customer). As the owner, a member is obliged to invest. As a member investor is entitled to receive the investment proceeds. On the other hand as a customer, a member is obliged to participate in every business transaction in the cooperative. In order to reflect the principles of justice, democracy, transparency, and in accordance with the principles of cooperatives, it is necessary to consider the principles of division of SHU, among others:

- SHU divided is sourced from members.

- SHU members are services of capital and business transactions conducted by members themselves.

- The sharing of SHU members is done transparently.

- SHU members are paid in cash.

Understanding financial statements: In practice the financial statements by companies are not made in a haphazard manner, but must be created and prepared in accordance with the rules or standards applicable. The financial statements presented by the company are very important for the management and owners of the company. In the case of financial statements, it is an obligation of every company to create and report the company's finances at a certain period. The reported things are then analyzed so as to know the condition and position of the current company. Then the financial statements will also determine what steps the company is doing now and in the future, by looking at various problems that exists both weaknesses and strengths it has. Munawir [7] concluded that: The financial statements are two lists prepared by the accountant at the end of the period for a company. The second list is a list of balance sheets or lists of financial positions and a list of earnings or income-earning lists. In recent times it has become customary for corporations to add a third list of surplus lists or undistributed earnings lists on hold). In general, the financial statements consist of balance sheet and profit and loss statement and capital change report, in which the balance sheet shows/describes the 
amount of assets, debt and capital of a company on a certain date, while the calculation (profit and loss statement shows the results that have been achieved by the company as well as costs incurred over a certain period, and reports of changes in capital indicate the source and use or reasons that led to changes in company capital. But in practice often included other groups that help to obtain further explanations, such as reports on changes in working capital, and use of cash or cash flow statements, reports of causes of changes in gross profit, production cost reports and other lists. Halim Dan Mamduh [8] gives the limit that "Financial statements are one important source of information besides other information such as information industry, economic conditions, market share of companies, quality management". The financial statements show that the figures in rupiah seem to be exact and exact, but in fact the basis of the arrangement with the standard values that may be different or changing. The financial statements are made on the basis of going concerns or responses that the company will proceed so that the fixed assets are valued based on historical or acquisition value and the deduction is made against such fixed assets in the amount of accumulated depreciation. Harahap [9] provides a limitation that "Financial Statements is to describe the financial condition and results of a company's business at a certain time or a certain time period". A financial report that has been examined by a public accountant is more important, because the report has been compared or matched with accounting records by an independent accountant to corporate management. General accountants by conducting research with standard and common inspection procedures will give their opinion on the fairness of the financial statements tested by the company (Balance Sheet and Income Statement), that the report is in accordance with the usual accounting principles and has been applied consistently from year to year. From the above theories can be concluded that the financial statements are the result of an important accounting process and can be used to make economic decisions for internal parties and external parties company. Portraits on the company that is, can describe the financial performance and performance of company management, whether in good condition or not. Then summary of a process of financial transactions that occur during the period will be in question.

Types of financial statements: The types of financial statements presented there are three types of financial statements in cooperatives under PSAK No.27 of 2007, among others:

- Income statement profit and loss statement shows the condition of the business within a certain period. That is the income statement must be made in a cycle of operation or a certain period in order to determine the amount of revenue and expenses that have been issued so that can know whether the company in a state of profit or loss.

- The owner's equity report: The owner's equity report is an overview of owner's equity changes that occur during a certain period. For example a month or a year. Owners' equity reports report changes in owner's equity over a period of time. The report is prepared after the income statement, since the net income or net loss of the current period should be reported in this report.

- Balance Sheet: A balance sheet is a report showing the amount of assets (assets), liabilities (debt), and capital (equity) at a given moment. Balance sheeting is usually made based on a certain period (annual).

Source of cooperative capital: The source of cooperative capital is sourced from member's capital. Source of cooperative capital according to Law No.25 Article 41 Year 1992, among others:
- Deposits of principal: A certain amount of money is worth as much and that must be paid by each member.

- This type of principal savings cannot be retrieved as long as the person is still a member of the cooperative.

- Deposit required: The specified storage amount and must be kept by each member at a certain time. Deposits shall only be retrieved in the manner specified in the articles of association.

- Reserves funds: The portion of the allowance for nondistributed share of the business proceeds to its member who is intended to cultivate its own capital and to cover the loss of the cooperative when needed. Grants the provision of funds from other parties for free is no obligation for cooperatives to pay back either in the form of principal or services that can be categorized as a grant to the cooperative.

\section{Discussion}

\section{Duties and obligations of the board}

Leading the organization and business of the cooperative as well as representing it upfront and out of court in accordance with the decisions of the member meeting. Holding Annual Membership Meetings (RATs) according to the conditions stated in the articles of association. Reporting to members' meetings of all matters concerning the life of the cooperative and all reports of inspection on the life of the cooperative especially on the written report of the examiner body and also convey the copy to the official. Providing assistance to officials performing their duties by providing information requested by officials and showing all the books, treasuries, inventories and other assets that become and the wealth of the cooperative. Conducting or organizing books of organization and business administration in accordance with the provisions stipulated by the official. Maintaining the harmony of members and serving them as well as possible, among others, in terms of receiving opinions on the advice of members outside the meeting.

\section{Duties and authorities of supervisors}

Monitoring the traffic of activities undertaken by cooperative management; assist in giving opinion advice to cooperative core management.

\section{Duties and authorities of the chairman}

Be fully responsible in everything done by the member where the accountability must be shown to the supervisor and the management of the cooperative.

\section{Duties and powers of the secretary}

Manage the traffic of all fields, incoming or outgoing letters, in and out of file bills, letters of agreement and maintenance of the cooperative archives.

\section{Duties and powers of the treasurer}

Arranging finances in lending and storage of members of cooperatives. Where the calculation of lending is done in accordance with the ability of members and the calculation of the loan through a cut in the personnel section.

\section{Duties and powers of branch manager}

Task Manager is to coordinate all business activities, administration, organization, and implementation and provide administrative services to the board and supervisors. Authority shall take follow-up action on the policy which has been determined by the management. 


\section{Duties and powers of branch manager representatives}

The task and authority of the branch manager's deputy is almost the same as the branch manager who is jointly responsible for the member meeting. In addition, the branch manager's representative can also replace the branch manager if the branch manager is unable to attend.

\section{Duties and powers of administration division}

Set up the correspondence in the cooperative; Filing important cooperative documents; Monitor household needs and ATK cooperatives; preparing cooperative meetings; Schedule activities undertaken in the cooperative.

\section{The duties and powers of the marketing division}

The task of general marketing is to serve all the needs of prospective members or members of the cooperative regarding the application of membership, loans and deposits.

\section{Duties and powers of the finance division}

Coordinate and supervise cashiers, service units, and savings and credit units; conducting transactions on members who want to make savings and loans; Prepare data on financial development of business and its field periodically; Together with staff and managers prepare letters and meeting board members.

\section{Research Result}

\section{The role of the result of effort on financial statement}

Based on the records of observation reports that in the acquisition of income there are factors that can affect the size of the income from the rest of the business results include the capital consisting of voluntary donations and capital participation of members, savings consisting of principal savings and mandatory savings, and participation members in the distribution of the remaining income of the cooperative business saving and self-managed business. So the acquisition of the remaining business results for the cooperative every year becomes very important. Through the rest of the business the cooperative can cultivate its own capital with the reserve fund set aside at the end of the book closing period, thus strengthening its capital structure. The remaining results of the operations distributed to the members are the residual proceeds derived from or produced by members and non-members of the self-savings and loan cooperative business. If the nature is not derived from the economic activities of members of the cooperative then the rest of the proceeds will not be distributed but will be used as a reserve. Then in the division must be done transparently in a transparent sense is openly in its division. Basically every business run by the cooperative savings and loan aims to obtain the appropriate Business Return (SHU) for each member. In general, financial statements have been presented in accordance with the standard which has been determined, but still a financial report has its own characteristics and limitations. This can be found both in the financial statements of general companies such as services and manufacturing and in the financial statements of the cooperative. The nature and limitations of cooperative financial statements are similar to those of other financial statements, and one of them is the existence of conservative financial statements in the face of future uncertainty. The reason of accounting conservatism is done because the tendency to be pessimistic is considered necessary to offset the excessive optimism of the managers and owners so as to reduce the action of earnings management.

\section{Calculation of SHU shares against the financial statement}

Based on the records of observation reports that in the calculation of the distribution of the remaining results of operations have a percentage in each fund in the cooperative savings and loan business independently. Based on the self-financing cooperative savings loan, the percentage of each fund consists of $40 \%$ cooperative reserves, $25 \%$ member services, $20 \%$ capital services, and other services $15 \%$. Some of the funds from the calculation of the remaining results will be allocated into various funds such as education funds, social funds, and development funds. The distribution of the residual income of the business should be proportional to the business services performed by each member with the cooperative savings and loan business independently. To calculate the SHU division, beforehand requires some basic information, including:

- SHU Total, SHU contained in the balance sheet or income statement of the cooperative after tax.

- Member transactions, economic activities between members of the cooperative.

- Participation of capital, the contribution of members in providing capital cooperatives, namely the form of principal savings, mandatory savings, business savings, and other deposits.

- Turnover or business volume, total value of sale or receipt of goods or services in a period of time or year of book in question.

- Section (percentage) of SHU for member's savings, SHU taken from member's SHU, which is intended for member's capital services.

- Section (percentage) of SHU for member business transactions, SHU taken from members' SHU, intended for member transaction services.

After we get some information, as for the provisions in the division of SHU, among others:

- According to Law No.25 / 1992 article 5 paragraph 1 says that the division of SHU to members is done not solely based on the capital owned by a person in the cooperative, but also based on the balance of business services members to the cooperative. This provision is a manifestation of kinship and justice.

- In the AD/ART the cooperative has been determined in SHU division including: $40 \%$ cooperative reserve, $40 \%$ member services, $5 \%$ management fund, employee fund, $5 \%$ education fund, $5 \%$ social fund, $5 \%$ development fund.

- Not all of the above components must be adopted in dividing the remaining results of operations. This depends on the decision of the member specified in the member meeting.

SHU Per Member:

SHUA $=J U A+J M A$

Where, SHUA: Residual Member Result of Business; JUA: Member Services; JMA: Member Capital Services

$$
\text { SHUpa }=\frac{\mathrm{Va} \times \mathrm{JUA}+\mathrm{Sa} \times \mathrm{JMA}}{\mathrm{VUK} \times \mathrm{TMS}}
$$

With a mathematical model:

Where SHUpa: Residual Result of Business Per Member; JUA: 
Member Services; JMA: Member Capital Services; VUA: Member Business Volume (total member transactions); VUK: Total Business Volume Cooperative (total cooperative transactions); Sa: Total Member Savings; TMS: Total Own Capital (total member savings). The results shown in Table 1 are from the calculation of the remaining results of operations (SHU) period 2014-2016.

\section{KSP business performance mandiri branch office}

KSP Performance Mandiri Enterprises will be a measure of achievement tailored to the level of ability that can be done. Performance can be described as the level of achievement of the implementation of an activity in realizing the goals, objectives, vision, and mission koperasi. Berdasarkan observation note that the rest of the business results distributed to members cooperatives should be paid in cash to the members because then cooperative savings and selfmanaged businesses can prove himself as a sound business entity to members and the community of its business partners. The savings and loan business activities undertaken by the self-sustaining loan and selfmanaged cooperative business perform well.

The development of self-savings and loan cooperative business basically can be seen from several indicators such as the number of members, business volume, and capital. In addition, the performance of the board in the KSP Usaha Mandiri is very necessary in all activities undertaken by the cooperative, and very closely related to carefulness of the KSP Mandiri Business in providing loans to customers. Given the good performance and in accordance with the requirements of the Articles of Association of the cooperative law, the results achieved will also be good. Furthermore, the performance of the manager in KSP Usaha Mandiri is closely related to the role of a leader in carrying out tasks that can provide new innovations and policies that can improve in the acquisition of the rest of the business results. The performance of the manager also greatly determines the course of all activities undertaken by cooperatives and has authority over all things that are internal. Then, employee performance in KSP Usaha Mandiri is an ability where an employee in becoming a member of cooperative.

The existence of a self-sustaining lending cooperative business will be assured if the business performance shown by the cooperative savings and loan business is a significant growth and is strongly supported by good rules and policies and sound practices to improve economic and business capability and member income. The disadvantage of a selfsustaining business loan cooperative is the absence of a guarantee in the lending process and the trust capital of the member. Therefore, it is necessary to cooperate among related parties in fixing the existing weaknesses in developing self-savings and loan cooperative business so that later can become a good and healthy non-bank financial institution and trusted by many people.

\section{Conclusion}

Based on the explanation of the results of research and discussion that has been done by the authors can be concluded as follows:

The remainder of the business result is a business result derived from the business results or the income of the cooperative during a fiscal year after deducting expenses on operating expenses. The role of the rest of the business results on the financial statements is the acquisition of the remaining results of operations on the cooperative is a success for the cooperative because the cooperative is an institution engaged in the economy because it cannot be separated from the income that has been obtained during a book year. With the rest of the results of operations within the cooperative can cultivate own capital where with the reserve funds that can be set aside in each closing period of the book, because it can strengthen the capital structure. Any business undertaken by a savings and credit cooperative is aimed at obtaining the remaining results of operations.

Based on the Annual Members Meeting (RAT) of the independent savings and loan cooperative business, it has been determined that the percentage in the distribution of the remaining business proceeds is for $40 \%$ cooperative reserves, $25 \%$ member services, $20 \%$ capital services, and other services $15 \%$. The remaining business results in the cooperative savings and loan business from 2014 to 2016 always increase. The development of residual business results tends to increase from year to year leading to improving corporate conditions. In 2014 the remaining results of operations obtained by members of Rp. 337.752, -. Then in 2015 an increase of Rp. 669,467, -, and in 2016 increased again by Rp. 718.093, -. Factors that may affect the increase of business results in self-savings and loan business cooperatives are self-capital consisting of principal savings and mandatory savings, and member participation.

The performance of the self-sustainable lending cooperative business will be a measure of achievement that has been adjusted to the level of ability. Then can be described as a level in the achievement of implementation in an activity to realize a goal, goals, vision and mission of cooperative savings and loan business independently. With the existence of business activities on the cooperative savings and loan business independently it can be seen the development that basically can be seen from several indicators such as the number of members, business volume, and capital. In addition, the performance of managers, managers and employees can assist in developing cooperatives. The existence of a self-sustaining lending cooperative business will be guaranteed if the business performance shown by the cooperative savings and loan business is a significant increase in business growth.

Furthermore, from the conclusions obtained, the suggestions are:

Basically the remaining business return is only the residual proceeds derived from or generated by members of the cooperative.

\begin{tabular}{|c|c|c|c|}
\hline & 2014 & 2015 & 2016 \\
\hline SHU & Rp. 51.309.000,- & Rp. 82.416.200,- & Rp. 158.489.200,- \\
\hline Reserves of cooperatives & Rp. 20.523.600,- & Rp. 32.966.480,- & Rp. 63.395.680,- \\
\hline Member services & Rp. 12.827.250,- & Rp. 20.604.050,- & Rp. 39.622.300,- \\
\hline Capital services & Rp. 10.261.800,- & Rp. 16.483.240,- & Rp. 31.697.840,- \\
\hline Other services & Rp. 7.696.350,- & Rp. 12.362.430,- & Rp. 23.773.380,- \\
\hline Percentage of member services & $2,4 \%$ & $2,9 \%$ & $5,5 \%$ \\
\hline Percentage of capital services & $14 \%$ & $16 \%$ & $16 \%$ \\
\hline Result of sharing period of result of business per member & Rp. 337.752,- & Rp. 669.467,- & Rp. 718.093,- \\
\hline
\end{tabular}

Table 1: Results of the calculation of the remaining results of the business (SHU) and ShU division of members period year $2014-2016$. 
Distribution of the remaining results of operations conducted transparently in the sense of a process of calculating the remaining results of operations per member and the amount of residual results of operations divided to members must be announced in a transparent or open. Pembagian residual results per member must be given in cash, because then cooperative store self-lending business can prove itself as a healthy business entity to its members. Factors that can affect the amount of income in the remaining results of business in the cooperative savings and loan business is a form of capital consisting of deposits, and participation of members. In the division of profit in the distribution of the remaining results of operations should be proportional to the business services undertaken by each member of the cooperative savings and loan business independently.

In the calculation of the remaining shares of business proceeds, the remaining portion of the proceeds will be allocated to various funds such as social funds, education funds, and regional development funds. In the calculation of the division of the remaining business results, there is a percentage for each fund in the distribution of the remaining business proceeds in the standby cooperative, such as $40 \%$ cooperative reserves, member services $25 \%$, capital services $20 \%$, and other services $15 \%$.
In the performance of cooperative savings and loan business independence required the cooperation between parties concerned to improve the existing weaknesses in developing cooperative savings and loan business so that the future becme a good cooperative and healthy and trusted by many people.

\section{References}

1. Hendrojogi D (2007) Cooperatives: Principles, theories and practices. Edition 4. Jakarta: Rajawali Press.

2. Sudarwanto A (2013) Cooperative accounting: A practical approach to preparing financial statements. Yogyakarta: Graha llmu.

3. Burhanuddin (2010) Easy establishment of cooperative procedures. First Print. Yogyakarta: Pustaka Yustisia.

4. Rudianto SS (2010) Accounting cooperatives. Second Edition. Jakarta: Erland

5. Widiyanti N, Sunindhia YW, Zahrah IMA, Syaury A (2009) Cooperatives and the Indonesian economy.

6. Limbong B (2012) Cooperative entrepreneur strengthens people's economic foundations. Second printing. Jakarta: Margaretha Pustaka.

7. Munawir (2010) Financial statement analysis. Fourth Edition. Yogyakarta: Liberty.

8. Halim A, Mamduh MH (2009) Analysis of financial statements. Edisi Yogyakarta: UPP STIM YKPN.

9. Harahap SS (2007) Critical analysis of financial statements. First Edition Jakarta: PT. Raja Grafindo Persada. 